Vítor Daniel Pires Ferreira

Faculty of Letters, University of Coimbra, Centro de Estudos de Geografia

e Ordenamento do Território (CEGOT)

UDC: $338.48-6: 7 / 8(430)$

\title{
THE CULTURAL HERITAGE TOURISM IN THE CITY OF HEIDELBERG, GERMANY: PLANS, MOTIVATIONS AND REALITIES
}

\begin{abstract}
In recent years, heritage has been responsible for the visibility that a large number of cities around the world have been getting as regards affirmation and differentiation of places. This also increased the number of cultural tourists that visit those cities worldwide. In this struggle for affirmation and differentiation, Heidelberg has quite an advantage, since the city's cultural heritage, as well as its unique atmosphere, have been spread by the Romantic Movement in the $19^{\text {th }}$ century and it still happens nowadays, after more than two hundred years.

But is Heidelberg indeed a city that receives cultural tourists? In this article, through an exploratory study, we intend to characterize the tourists that visit the city, to understand if the defined politics, actions and events taken by the different institutional authorities (like the Heidelberger Marketing and City Town hall, among others) are getting the expected results.
\end{abstract}

\section{Introduction}

Globalization has brought renewed attention towards assets that allow the assertion of places in a context where it global culture prevail (Ferreira, 2011; Lipovetsky\&Serroy, 2010). The diversification of consumer experiences allows that culture and heritage assets have a central place in this unbridled fight for affirmation.

Territories, in this struggle for affirmation and differentiation, rely upon patrimonial assets, or events, whether they are cul-
Through literature review and questionnaires completed by the city's tourists, based on a probabilistic random sample and semi-structured interviews, we expect to trace the evolution of the policies defined, and compare those to the type of tourists that actually visit the city.

As a preliminary result, we concluded that there is a difference between the tourist profile defined by the institutional authorities with responsibilities in the promotion and communication of the city's cultural heritage assets, comparing with the tourists that actually visit the city. This is the result not only of the motivations and effective length of the visits, but also in the lack of alternative or multiple visit narratives and routes for the cultural heritage city's assets.

Keywords: cultural tourist, cultural heritage, policies, results, heidelberg

tural, recreational or sportive, in a strategy to increase the number of visitors, in one hand, but also in an attempt to captivate cultural tourists.

This process of this affirmation, usually, involves the draft of local and/or regional development strategies anchored in culture. In this general concept of culture we can find the heritage assets, as well as the cultural events, which are systematically anchored to local development strategies and to the differentiation of territories strategy in this global competition. 
Although Afonso (1996) have argued that all indicators pointed to the increasing development of appetite for tourist enjoyment of historical and cultural heritage and that cultural tourism, so far, has been considered the industry of the future, the reality has changed over the past decade. Not having cultural heritage lost its appealing power, the truth is that, as estimated by CarmindaCavaco (1996), new forms of tourism prevail, softer, lighter, handmade, human, particular and differentiated where the endogenous and the authentic prevails adjusted and in harmony with the place of destination.

It is important to point out the excess of offers concerning cultural tourism and certain massification and non-differentiation of the products available to the tourists announcing the bankruptcy of this tourism model (Fernandes\& Ferreira, 2012). First of all, the paradigm of passive consumption no longer holds and, secondly, according Hewinson, there has been, a museumfication of modern life or, as mentioned by Edensor and Judd (both cited by Richards \& Wilson, 2006), one homogenization of tourist spaces. Still, it is premature to announce the ruin of cultural tourism, since the increasing demand led to the differentiation of it in specialized submarkets such as heritage, gastronomic, literary, architectural, artistic, cinematic tourism, among others.

We stand here before an almost fetishistic creation of dozens of different lists of types of heritage, as stated by Harrison (2010). We could say that the evolution which the concept of cultural heritage has in recent decades at a conceptual level, is a portrait of the legislative and directive growths, either having a national or international nature, but also a reflection of contemporary societies and the opening of the semantic gap of the concept.

A triple extension of the concept is now universally accepted and, as mentioned by Vecco (2010), it consists of a typologi$\mathrm{cal} /$ thematic issue, as objects are embodied in the concept which are not part of the traditional concept, and a geographic and chronological extension as it has been given heritage a status, adding that the patrimonial assets and monuments are not seen as isolated things, but in relation with the context, which implies the adoption of a holistic approach in its questions. Based on the above, it is understandable that patrimonial assets considered minor until then, compete in these local assertion strategies, either because of cultural or tourism aims, in parallel with larger estates. It is important to retain that the size of these patrimonial assets is more often the result of a more instrumental choice of the government (Heinich, 2009) than of the communities that experience it and for whom it has the same values of identity, memory and history.

And this instrumental choice, or manipulated choice in favor of the promotion of the territory, is possible to be verified through the choices made by the institutions responsible for promoting tourism in the city.

\section{Territorial and institutional context}

Heidelberg is a city in Germany (see Figure 1) sited on the Neckar river valley, in northwest Baden-Württemberg. It is the fifth largest city in the state of Baden-Württemberg which is administratively an urban district, or "Stadtkreis", in other words, it is constituted as an administrative district "Kreis". It depends on the "Regierungsbezirk" of Karlsruhe.

The historical importance of Heidelberg is essentially due to the fact that it was the city residence of the Electorate of the Palatinate, but also because it has the Ruperto Carola University, the oldest in the current German area, founded in 1386.

The development of the city is owed to the need for affirmation and consolidation of the Count Palatine of the Rhine; that need was felt by the half-brother of Fred- 
erick I Barbarossa, Konrad from 1156. This affirmation and strengthening of power was primarily aimed to fight the influence of the Bishop of Worms and the Abbey of Lorsch (Cser, 2007). The first source regarding the city appears only in 1196 . This source indicates Konrad as a witness, citing him as plebanus von Heidelberch. It is supposed that he belonged to the Court of the Palatinate, but as a Priest, he was also the spiritual counselor of the population of the city (Cser, 2007).

In the development of the city one can state that despite the wishes of political statement carried by dynastic territorial interests being central, the city gets a growing economic importance from mid- $13^{\text {th }}$ century. This happens due to its location and the growing importance of trade in general and wine trade in particular, which made the city prosper (Cser, 2007).

The sedentarization of power, with the disappearance of the itinerant courts, along with the increasing use of the city in the various festivities and royal ceremonies (Cser, 2007), caused the city to acquire the status of city residence of the Court of the Palatinate. The city's status continues to rise, because it has been the capital of the Holy Roman Empire, with Ruprecht I, between 1400 and 1410.

The $15^{\text {th }}$ century witnessed the major changes in the urban landscape of Heidelberg, with successive enlargements and improvements of the city, of which only the castle ruins came up to this day. The $17^{\text {th }}$ century, with the Thirty Years War and the Succession War, is marked by the destruction of the city, and the urban landscape, nowadays internationally recognized, with the exception of a dozen buildings in the Old Town such as the Hauszum Ritter, the St. Peter's Church, the Zeughaus, the Providence Church, among others, is the result of the Baroque reconstruction performed at the beginning of the $18^{\text {th }}$ century (Cser, 2007).

The best picture of the destruction is given by Cser (2007) when he says that, at the end of the Succession War, only 153 families remained in Heidelberg, a number that however it is assumed that is constituted by the returning inhabitants to the city and who had taken refuge in the surrounding forests.

It is the result of this historical process that is today offered to the visitors of the city, which had the Romantic Movement as one of the main promoters of this image of the city.

\section{Image 1 - Localization of Heidelberg}

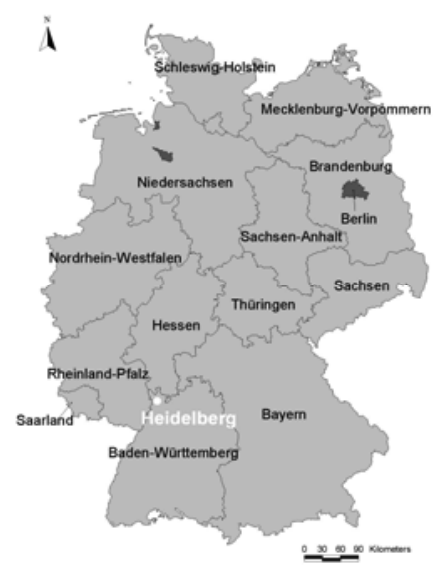

Source: Created by Diogo Azevedo

Over the past decades, the city has become one of the most popular German tourist destinations due to its built/architectural cultural heritage, like its Baroque historic center, but also the castle, in ruins. The heritage element, as mentioned, was essentially promoted by the Romantic Movement in the early $19^{\text {th }}$ century, and in parallel with Jena, Heidelberg was its main stage.

Along with the Acropolis of Athens, the Heidelberg castle is one of the most visited ruins in Europe, and in 2009 the city had about 4 million visitors per year (Crolly, 2009). In 2011 it only had about 3 million visitors (Wimmer, 2011). Of these visitors around one million visit the ruins of the the castle (Staatliche Schlösser und Gärten Baden-Württemberg, 2013). 
Regarding the institutional context, the City Hall of Heidelberg delegates the tourist promotion of the city and its heritage attractions to the Heidelberger Marketing $\mathrm{GmbH}$. The Heidelberg Marketing $\mathrm{GmbH}$ is an affiliated company of the city of Heidelberg that plans, coordinates and implements measures in the context of urban marketing in Heidelberg, which include the activities for the promotion of tourism, conferences, of the Kongresshaus Stadthalle Heidelberg and the Tourist Information Service.

In parallel, promoting the Heidelberg Castle is not a responsibility of the Heidelberger Marketing, but rather of the SaatlicheSchlösser und Gärten Baden-Württemberg which is an incorporated public-law institution (ÄOR) under the Finance Ministry of Baden-Württemberg. The statutes of the SaatlicheSchlösser und Gärten Baden-Württemberg include obligations, such as, according to Article 2, "an offensive and publicoriented presentation and marketing of the state palaces, convents, gardens, castles and ruins as well as their dependencies." Among the cultural assets that the SaatlicheSchlösser und Gärten Baden-Württemberg manages, we can find the Castle/Ruin of Heidelberg and the Palatino Garden, alongside the state's property of Baden-Württemberg.

We thus find a territorial space, where the promotion and diffusion of heritage and cultural assets for tourism purposes is dependent of a variety of public institutions. If, on one side, the City Hall of Heidelberg is responsible for promoting the Old Town and of the heritage property belonging to this historical center, the SaatlicheSchlösser und Gärten Baden-Württemberg is responsible for setting the policies for tourism promotion and use of the Castle and its surrounding garden, also known as HortusPalatinus.

In the definition of plans to promote the city's tourism we cannot ignore the cultural heritage authorities. In administrative terms the safeguarding and protection of cultural heritage in the state of Baden-Württemberg is organized hierarchically. This organization plays an important role in the definition of public policies toward tourism promotion of the city and especially of the city's cultural heritage. This is also a hierarchical organization that is constituted by the Finance and Economics Ministry from Baden-Württemberg as Top of the Cultural Heritage Authorities. This is followed by the upper authorities that are composed by the four regional councils, namely Freiburg, Karlsruhe, Tübingen and Stuttgart. In this last one we also find the State Office for Cultural Heritage, that is responsible (DSchG BW, 1983) to assist and support statewide all the other cultural heritage authorities in all matters related with cultural heritage. Among other things this Regional Council has also the responsibility to create statewide uniform criteria (DSchG BW, 1983) for evaluation and assessment of cultural heritage elements, but also to represent both internally and externally (DSchG BW, 1983), as well as to prepare all matters related with public relations to be carried out in coordination, with the referred top cultural heritage authority from the state.

At the bottom of the cultural heritage administration we find the lower cultural heritage authorities consisting of cities, towns, counties, and management communities. In the present case the lowest cultural heritage public authority is the Heidelberg City Council and his Office for Building Law and Historic Preservation.

Through the legislation applicable to cultural heritage, the organization of the authorities of cultural heritage, influences, or can influence, the design of strategies to promote tourism in the city, in that it may condition the uses and modifications in the interventions on heritage assets, these projects being intended to create touristic itineraries, visit tours, or to open commercial spaces adjusted to the tourism demands.

The legislation applicable to the cultural heritage, in the state of Baden-Württemberg 
(DSchG BW, 1983), is one of the oldest of the German Federal Republic and dates back to 1971. In its Article 2, paragraph 1, as cultural heritage are considered, the things, collections of things and parts of things, whose preservation has scientific, artistic or homeland historical public interest. The legislation also states that the surrounding area, as to influence in the lecture of the cultural heritage assets, must be safeguarded and preserved.

An example of how the protection of the heritage assets can influence the development of strategies for tourism promotion is the case of the Gesamtanlagenschutzsatzung (Stadt Heidelberg, 2003), or total plant protection statutes, for the protection of the area "Alt Heidelberg" of June $26^{\text {th }} 2003$. This Satzung (Stadt Heidelberg, 2003), or statute, foresees the protection of the entire old town of Heidelberg, and the Article 3 adds that "protection includes the outwardly acting image of the old town - as it offers the viewer from the slopes of the Neckar Valley - and the internal image of the embossed through the historic buildings streets and squares, as well as the visual axis of the Old Town on the slopes."

\section{Actions and plans versus results}

As mentioned, with this article it is intended to make a reflection about the positioning, the plans and the actions undertaken by the organizations with responsibility in promoting touristic assets in the city of Heidelberg.

By analyzing the Annual Report of the Heidelberger Marketing, and of the institution that preceded him, the Heidelberger Kongress und Tourismus GmbH, in 2005, we can see that the promotion of the city, according to Beate Weber (Heidelberger Kongress und Tourismus $\mathrm{GmbH}, 2006$ ), at that time mayor of Heidelberg, is based on cultural marketing. Cultural marketing is considered as playing a prominent role for city tourism, and that has been achieved by the integration of the cultural service into the institution. At the time, the Heidelberg ticket, was integrated in this structure, so that it is from now on responsible for the sale of tickets for events in and around Heidelberg. It is added that two events of the city, namely the The Heidelberger Frühling and the Castle's Festival (Heidelberger Kongress und Tourismus $\mathrm{GmbH}, 2006)$, have considerably strengthened Heidelberg reputation as a cultural city in the world.

On the other hand, Nils Kroesen, managing director of the Heidelberger Kongress und Tourismus GmbH (2006) puts the emphasis on the achieved number of tourists that visited the city, calculating the impact of the tourism in Heidelberg around 462 million euros with the creation of between 4,000 and 5,000 jobs in Heidelberg. Reading these Annual Reports, we can verify that the existing main concern is a quantitative matter. The objective is to increase the number of overnights stays per visitor, but also to promote the city into new markets such as the Arab Gulf States. The report adds that the first high-level contacts, in order to promote effectively the city's image, have been already undertaken in the major emerging markets of China and India (Heidelberger Kongress und Tourismus GmbH, 2006).

The concern with the number of overnight stays is frequent in the reports analysis, and in 2007, the Mayor, Dr. Eckart Wurzner, highlights that the numbers achieved in 2006, but also that they will be an encouragement for the development of new ideas and concepts to promote tourism in Heidelberg (Heidelberger Kongress und Tourismus $\mathrm{GmbH}, 2007)$.

We highlight also the investment of the institution in the Press and Public Relations (Heidelberger Kongress und Tourismus $\mathrm{GmbH} 2007$ ), which are considered a way to promote a positive image and offer of all the features of Heidelberg above regional and 
internationally level in a credible, effective and low-cost way.

In the Report of the Staatliche VermögensHochbauverwaltung-und Baden-Württemberg, an institution that has as a subsidiary the SaatlicheSchlösser und Gärten Baden-Württemberg, we only found reference related to the offer of attractive leisure activities in the world famous Heidelberg castle and gardens, among others (Staatliche VermögensHochbauverwaltung-und Baden-Württemberg, 2008). If we go back to 2006 , we can see that the heritage assets under their control should be presented as customer and service-oriented and convey by guides with knowledge, experience and quality education. The objects (castles, gardens, palaces) are to be made available to the many audiences through diverse, innovative offers in cooperation with several institutions and partners. It is also clearly stated that the aim is to finance the ongoing operations with this income, with minimal impact on the historical substance (Staatliche VermögensHochbauverwaltungund Baden-Württemberg, 2007).

From the analysis of the Reports of the two institutions, between 2005 and 2011, we can see that the main concerns lie in the field of commodification of history, which, as stated Greg Richards and Julie Wilson (2006), is due to political and economic needs. Although cultural heritage is currently understood as having three types of functions, refer to: cultural, economic and finally socio-political nature (Graham, B., Ashworth, GJ \& Tunbridge, JE, 2000), heritage, as a selection of the past to use in contemporary times, has these qualities clearly marked, being, however, also clear, as in this case, that the economic function tends to overlap the remaining ones. The same opinion has Rodney Harrison (2010) when he states that the boom of heritage and museums has led to an increasing commercialization of heritage, adding that this phenomenon distances people from their own heritage.

We stand so, as said by Garrod\&Fyall (2000), towards a cultural heritage tourist product design that has to be able to maintain its authenticity and the integrity of the site at the end, but must be able to deliver value for money, as well. This is also stated by the Heidelberger Marketing $\mathrm{GmbH}$, as it is now, a reconfigured institution, which pursues as core task the professional, worldwide marketing of the city on the basis of a modern, holistic marketing concept, which include tourism and congresses but also includes science, industry, retail and culture (Heidelberg Marketing GmbH, 2008).

\section{Chart 1 - Heidelberg Tourist Overnights 2005-2012}

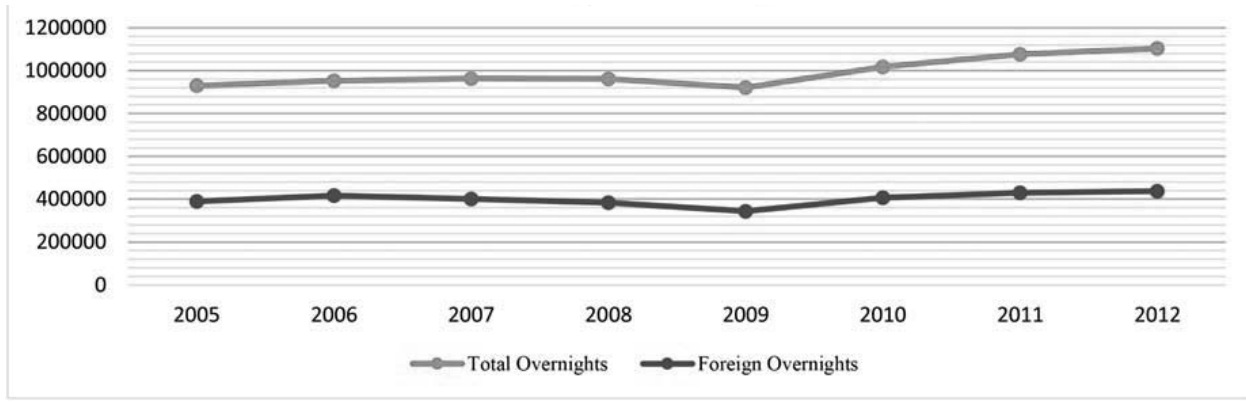

Source: Statistisches Landesamt Baden-Württemberg, Stuttgart, 2013 
When analyzing the total overnights stays/year in Heidelberg, between 2005 and 2012 (see Chart 1), we can see that although we are facing a raise, this is not really significant, despite all the significant investment on the promotion of the city regarding new markets and developing markets. This raise, when analyzed both ends of the period, appears as high, since between 2005 and 2012 we can verify an increase of $15,74 \%$ in the total of overnight stays, but we also see an increase of only $10,94 \%$ of overnights regarding foreign visitors. However, this increase is not linear, because we can see a regression in the years 2007, 2008 and 2009, for example, concerning the overnight stays of foreign tourists of $-3,68 \%,-4,74 \%$ and $-11,44 \%$, respectively. It is peculiar that this decrease happens immediately after the reorganization of the Heidelberger Marketing $\mathrm{GmbH}$, the institution responsible for the tourism promotion of the city, and its focus on the holistic marketing concept, as mentioned.

If we look at the chart, the percentage of overnight stays of foreign tourists compared to the total number of overnights, not only it doesn't increase but it decreases in the analyzed period. In 2005, 41,85\% of overnight stays were attributed to foreign tourists, in 2012, at the other end of this analysis, this number falls to $39,59 \%$. Thus, it is suitable to question the investment in new foreign markets, when the tourists most represented in the city have German origin. If we consider the average length of stays between 2005 and 2012 (StatistischesLandesamt Baden-Württemberg, 2013) we can see that there was a slight increase in the average: 1,7 nights per visitor, in 2005, and 1,9 nights per visitor, in 2012.

We may conclude that the decrease of foreign visitors did not represent a significant impact on the average of nights that every tourist stayed in Heidelberg.

This case study is established as an exploratory and initial study, about the identification of visitor with the different cultural heritage in the city of Heidelberg, the values and the importance they attribute to it.

The questionnaires are bilingual (German and English, or French, or Spanish, or Portuguese) and were conducted among the one defined group, the visitors of the city of Heidelberg, between April 2013 and August 2013. These questionnaires are based on a random probability sample constituted of 166 respondents of the defined group for an infinite population. The setting this number of respondents is based on achieving a Confidence Level of 99\% and 0.1 Margin of Error (Krejcie\& Morgan, 1970; Kenny, 1986). This survey was conducted among visitors of the city of Heidelberg by monitoring the guided tours, conducted via Heidelberger Marketing, Gästeführere.V. and the administration of the Heidelberg Castle.

The country of origin of the visitors with higher representation in the sample under analysis (See Table 1) is Germany with $24,70 \%$, France with $11,45 \%$, followed by Brazil with 9,64\% and Spain with 9,64\%. With the sample analysis we concluded that the average duration of the visit to the city of Heidelberg is around 28,90 hours per visitor, which corresponds to an average stay of 1,20 days per visitor.

Based on the countries of origin of the visitors with higher expression in the sample, Germany, we find that, in the case of these visitors, they stay an average of 40,98 hours in the city, which corresponds to 1,71 days per visitor. In the case of visitors from France, $11,45 \%$ of the sample, we can see that these only remain in the city an average of 8,79 hours, which corresponds to 0,37 days per visitor. We found identical average in the case of visitors from Brazil, 9,64\% of the sample, with 9,00 hours of visit, that is, 0,38 days per visitor. In the case of Spanish visitors, $9,64 \%$ of the sample, the average of visit lies in 4,81 hours, or 0,20 days per visitor. In the case for visitors living in Portugal, the fourth most significant case with $7,83 \%$ of the sample, the average hours of stay in the 
Table 1 - Descriptive Statistics Country of Origin

\begin{tabular}{|c|c|c|}
\hline Variables & $\begin{array}{c}\text { Frequency } \\
(\%)\end{array}$ & $\begin{array}{c}\text { Average } \\
\text { length }\end{array}$ \\
\hline \multicolumn{3}{|l|}{ Country of Origin } \\
\hline Argentina & 4,22 & 18,29 \\
\hline Australia & 3,61 & 34,00 \\
\hline Belgium & 3,01 & 34,80 \\
\hline Brazil & 9,64 & 9,00 \\
\hline Canada & 3,01 & 110,40 \\
\hline China & 0,60 & 48,00 \\
\hline France & 11,45 & 8,79 \\
\hline Germany & 24,70 & 40,98 \\
\hline Holand & 0,60 & 48,00 \\
\hline Mexico & 0,60 & 17,00 \\
\hline New Zealand & 0,60 & 8,00 \\
\hline Norway & 0,60 & 24,00 \\
\hline Portugal & 7,83 & 23,38 \\
\hline Russia & 1,20 & 48,00 \\
\hline South Africa & 0,60 & 24,00 \\
\hline South Korea & 1,20 & 24,00 \\
\hline Spain & 9,64 & 4,81 \\
\hline Sweden & 1,81 & 56,00 \\
\hline Switzerland & 0,60 & 24,00 \\
\hline Taiwan & 0,60 & 8,00 \\
\hline Turkey & 1,20 & 48,00 \\
\hline UK & 3,01 & 4,60 \\
\hline $\mathrm{UAE}$ & 1,81 & 17,67 \\
\hline USA & 7,83 & 52,54 \\
\hline
\end{tabular}

city increases to 23,38 hours, corresponding to 0,97 days per visitor.

Among all the countries of origin of the visitors in the sample under analysis, the one with longer duration of stay in the city is Canada with 4,6 days per visitor, that correspond to an average of 110,40 hours per visitor spent in the city. However, the number of Canadian visitors consist in only 3,01\% of
Table 2 - Descriptive Statistics - Gender, Age Groups, Education and Context of Visit.

\begin{tabular}{crr}
\hline Variables & $\begin{array}{c}\text { Frequency } \\
(\%)\end{array}$ & \multicolumn{1}{c}{$\begin{array}{c}\text { Average } \\
\text { length }\end{array}$} \\
\hline Gender & & \\
Male & 41.57 & 28.96 \\
Female & 58.43 & 28.87 \\
Age Groups & & \\
$</=15$ & 1.20 & 24.00 \\
$15 / 24$ & 12.05 & 19.85 \\
$25 / 34$ & 7.23 & 47.33 \\
$35 / 44$ & 10.24 & 35.71 \\
$45 / 54$ & 16.27 & 46.19 \\
$55 / 64$ & 18.67 & 33.23 \\
$65 / 74$ & 21.08 & 19.49 \\
$=/>75$ & 13.25 & 9.95
\end{tabular}

Education

$\begin{array}{lrr}\text { Primary School } & 4.82 & 13.50 \\ \text { Middle School } & 6.63 & 16.18 \\ \text { High School } & 16.87 & 31.36 \\ \text { Vocational Edu. } & 12.65 & 32.62 \\ \text { Bachelor } & 28.31 & 24.72 \\ \text { Master } & 19.28 & 39.22 \\ \text { PhD } & 6.02 & 33.50 \\ \text { Other } & 0.60 & 5.00 \\ \text { Dk/Da } & 4.82 & 24.00\end{array}$

Context of Visit

Independently $\quad 27.71 \quad 51.76$

$\begin{array}{lll}\text { Guided Group } \quad 68.07 & 19.98\end{array}$

$\begin{array}{lll}\text { Others } & 4.22 & 22.71\end{array}$

the total number of respondents in the analysis. Another case to point out is the case of the U.S. visitors, which represents $7,83 \%$ of the total sample, that remain in the city of Heidelberg an average of 52,54 hours, that is 2,19 days per visitor.

Regarding the visitors gender (see Table 2 ), we cannot find significant differences in the average of stays in the city between the 
two groups. Although, in the age groups analysis we can conclude that the age group that has a higher average stay in the city is constituted by visitors between 25-34 years of age with an average stay of 47,33 hours, which corresponds to 1,97 days. The second age group with a higher average of stays consists in visitors with between 45-54 years of age who stay an average of 46,19 hours in the city, that is 1,92 days.

On the other hand, the age group most represented in the sample, $21,08 \%$ of respondents, that is the visitors between 64-74 years of age, just stays in Heidelberg an average of 19,49 hours, which corresponds to 0,81 days. In the age group between 55-64 years of age, which corresponds to $18,67 \%$ of the sample, the average of stays increases to 33,23 hours, corresponding to 1,38 days.

If we consider the visitors between 5564 years and those between $65-74$ years, we look at $39,75 \%$ of the total sample and we can see that the average of stay is placed in 26,36 hours, that is, 1,10 days per visitor.

Concerning the educational qualifications, it is clear that the duration of the stay increases with the educational background of the respondents, being the ones with a master's degree those with the longest duration of stay with 39,22 hours or 1,63 days, followed by the visitors with a PHD degree with 33,50 hours, corresponding to an average stay of 1,40 days.

Finally, it is also worth noting in this analysis that the context of the visit has a clear influence on the duration of the visitors stays. If the visit is organized independently, the average duration of stay is located in 51,76 hours, an average of 2,16 days per visitor, which clearly contrasts with the length of stay of those visiting the city through guided groups, that only remain in the city an average of 19,98 hours, 0,83 days.

As shown in the analysis, the average duration of stay in the sample in question is systematically below the average suggested by the institution responsible for the statis- tics in the state of Baden-Wuttemebrg, which considers that the average of 1,9 days per visitor in the year 2012 (StatistischesLandesamt Baden-Württemberg, 2013). This could be due to the fact that this sample is only the result of an exploratory study, or to the fact that the sample, being random, have been taken among groups of visitors with smaller planned stays in the city. It is, however, to infer that the same average will remain in subsequent studies to be undertaken with the full sample of 575 individuals.

The data revealed by the sample are indeed supported by semi-structured interviews conducted during the meeting with the Stadtteilverein "Alt Heidelberg", where interviewees Lutz Staedtler and Hans-Hermann Lindner say that the time frame of tourists (in Heidelberg) from Korea, from Japan, wherever, is so narrow that they have no time, twenty minutes even for a detour if needed (Stadtteilverein Alt Heidelberg, H.H. Lindner, L. Staedtler, Personal Communication, April, 15, 2013) adding that in such cases Heidelberg is removed from the organized tour circuits.

Ernst Gund, from the parliamentary group in the municipal council of Heidelberg elected by the Christlich Demokratische Union, shares the same opinion when he states that "today's tourism is, of course, a mass tourism. The bus arrives, then it stops briefly at the Old Bridge, you get off and get said: "now it is eleven o'clock, at three oclock you have to be back here», than the bus comes again, and moves on." (Christlich Demokratische Union, Ernst Gund, Personal Communication, November 14, 2013).

For his part, the person responsible for the Heidelberger Marketing, Mike de Vries, (Heidelberger Marketing GmbH, M. de Vries, Personal Communication, July 22, 2013) states that "our strategy really says that we want to try to achieve a qualitative increase of tourism, which should also be simultaneously capable to consider the demands and needs of citizens and residents 
in Heidelberg", this in a perspective of safeguarding other non-tourist functions of the city and how visitors flow conditions the life in the city. More, it is clearly assumed that the strategy to promote the city is one where they do not have only tourism in view, but where they have culture, science and economy in the field of view and try to network all this fields together (Heidelberger Marketing GmbH, M. de Vries, Personal Communication, July 22,2013).

These testimonies, taken from the surveys carried out by semi-structured interviews, and regarding the issue of promoting the city and the type of effective tourism that visits the city, support the averages of visit duration obtained by the quantitative method.

The Prof. Dr. Michael Goer from Baden Württemberg State Conservation Office also states that the policy follow by the SaatlicheSchlösser und Gärten Baden-Württemberg, in which $60 \%$ of the budget must be a result of the structures incoming, creates the problem of them wanting to offer everything. He continues saying that they, Conservation Office, have to try to slow down a bit this type of positioning, which of course is not so easy, but that this is already in discussion in the case of the Heidelberg Castle (LandesamtfürDenkmalpflegeBaden Württemberg, Prof. Dr. Michael Goer, Personal Communication, November 15, 2013).

Concerning the policy set for the promotion of tourism in the city, Andreas Faltz, manager of the SaatlicheSchlösser und GärtenBaden-Württemberg, states that the actual results are not the responsibility of the Heidelberger Marketing or the policies defined by the institution that he leads, but that they are a result of the action of the providers, the agencies that sell Heidelberg for three or four hours, and that everything has to be seen in four hours (SaatlicheSchlösser und Gärten Baden-Württemberg, Andreas Faltz, Personal Communication, November 28, 2013).
The characterization of the policy followed by the different institutions in the city of Heidelberg could be summed up in the observation made by Lutz Staedtler and Hans-Hermann Lindner (Stadtteilverein Heidelberg, HH Lindner, L. Staedtler, Personal Communication, April 15, 2013) that said that "this is a tourism that brings nothing to the city except a greater number of visitors."

\section{Conclusion}

Given the above, either through the analysis of quantitative data or the brief exploratory study of the quantitative data, it is possible to reach to the conclusion that there is a difference between the policies determined by the institutions with political responsibility in the field of tourism promotion and heritage assets and the results of these policies.

Despite being argued that the heritage communication strategies should take account of some aspects as segmentation, targeting and positioning (Misiura, 2006), having in mind that these are essential in the comprehension of the message that the different agents are giving about the cultural heritage and the city, this is only being defended in theory and not in the effective city promotion policies.

The main attraction of the city is, and will be, his cultural heritage that is, or could, serve as an anchor in attracting other tourists profiles, notwithstanding the fact that care must to be taken, that in the promotion of cultural heritage we have several factors that should be taken in account, namely the social, political, technological and the economic factors (Misiura, 2006). It seems, in this case, that we stand by a situation where their main concern it's essentially economi$\mathrm{cal}$, and where the main stakeholders are aware of the tourism consequences, but also where the emphasis is to get more and more 
economic dividends from the city's cultural heritage assets.

We can hardly say that we have a cultural tourism in Heidelberg, among the millions of visitors, as seen by the quantitative data. There are some visitors that, when traveling independently, stay in the city for a longer period of time, but the reality is that the city's visitor profile is characterized by a short stay visitor, that can hardly be characterized as tourist, even less as a cultural tourist.

As we have seen, $71,1 \%$ of the sample are visitors that stay less than 24 hours in the city, so they can't be classified as tourists, but as same-day-visitor or excursionist. Only $28,9 \%$ of the sample's visitor are effectively going to spend the night in the city, and these are, therefore, the only effective tourists, or overnight visitor (United Nations, 2010).

The lack of time that visitors get to know the city and its heritage assets had also the perverse effect on the strategy conception, of not having been offered (or created) to them any visit alternatives, which consider the heritage assets beyond the historical center and the castle. The tourist pressure is, thus, felt in a small territorial fraction of the city, completely shattered by the supposedly tourist demand, and that ostracize other touristheritage attractions of the city.

Thus, we are dealing with a lack of alternative or multiple visit narratives and routes for the cultural heritage assets of the city that could be provided by the different stakeholders, whether public or private, and it seems that they interiorized that, taking into account the demand type, its creation is not required.

As observed with the promotion strategies analyzed and the effective results that the sample gives to cultural heritage visitor of the city, we conclude that cultural heritage policies, and the tourism promotion policies of the city, can be characterized as essentially deepgreen or ecocentric (Garrod\&Fyall, 2000) with an emphasis on economic growth. The desire of a soft tourism, in which tour- ists are educated to respect and even nurture the environment, regional, social and cultural treasures of the visited place, is until now just a fantasy in Heidelberg.

\section{Bibliography}

Afonso, S. L. (1996). As autarquias e a cultura como motor de desenvolvimento integrado. Meridionália: Revista do Pólo de Beja da Universidade Moderna, 1, 57-58.

Cavaco, C. (1996). Turismos de ontem e de Hoje: Realidades e Mitos. Em Cavaco, C. (coord). Turismos e Lazeres (pp. 1-13). Lisboa: Centro de Estudos Geográficos da Universidade de Lisboa.

Crolly, H. (2009, November 30). Heidelberg und der Massentourismus. Die Welt. Retrievedfrom http://www.welt.de/6075829

Cser, A. (2007). Kleine Geschichte der Stadt und Universität Heidelberg. Karlsruhe: Braun. ISBN 3765083372.

DSchG BW (1983) Gesetz zum Schutz der Kulturdenkmale des Landes Baden-Württemberg in der Fassung vom 6. Dezember 1983. Retrieved from

http://www.landesrecht-bw.de/jportal/ ?quelle=Jlink\&query=DSchG+BW\&psml=bs bawueprod.psml\&max=true\&aiz=true

Ferreira, V. (2011). Olhares sobre o património cultural. Idearte - Revista de Teorias e Ciências da Arte 7, 7: 61 - 72. ISSN 1647-998X

Ferreira, V., Fernandes, J.L. (2012). Urban Tourism: from Heritage to creativity. AECIT 2012 - Creación y desarrollo e Productos Turísticos: Innovación y enfoque experiencial. 21-23 Noviembre 2012, Galizia, España. ISBN: 978-84-616-1805-7.

Garrod, B., Fyall. A. (2000). Managing Heritage Tourism. Annals of Tourism Research, Vol. 27, No. 3, Great Britain: Elsevier: 682708

Graham, B., Ashworth, G. J., Tunbridge, J. E. (2000). A Geography of Heritage: power, culture and economy. London: Arnold. 
Harrison, R. (Ed.) (2010). Understanding the Politics of Heritage. Manchester University Press. Manchester, UK: Manchester University Press.

Heidelberg Marketing GmbH (2008) Geschäftsbericht 2007. Retrieved December 10, 2013, from http://www.heidelbergmarketing. de/fileadmin/Mediendatenbank/PDF/Jahresberichte/Jahresbericht2007HeidelbergMarketingGmbH.pdf

Heidelberger Kongress und Tourismus $\mathrm{GmbH}$. (2006). Geschäftsbericht 2005. RetrievedDecember 10, 2013, from http://www. yumpu.com/de/document/view/9114167/ das-jahr-2005-heidelberg-marketinggmbh

Heidelberger Kongress und Tourismus GmbH. (2007). Geschäftsbericht 2006. RetrievedDecember 10, 2013, from https://www. yumpu.com/de/document/view/5164437/ geschaftsbericht-2006-i-heidelberger-kongress-und-tourismus-gmbh

Heinich, N. (2009). La fabrique du patrimoine. De la cathédrale à la petite cuillère. Paris : Maison des Sciences de l'Homme. ISBN 9782735112647.

Kenny, D. (1986). Statistics for the Social and Behavioral Sciences. Canada: Little, Brown and Company Limited.

Krejcie, R.; Morgan, D. (1970) Educational and Psychological Measurement. 30. 607-610.

Lipovetsky, G., Serroy, J. (2010). A culturamundo: resposta a uma sociedade desorientada. Lisboa: Edições 70.

Misiura, S. (2006) Heritage Marketing. Oxford: Elsevier.

Richards, G., \& Wilson, J. (2006). Developing creativity in tourist experiences: A solution to the serial reproduction of culture?.Tourism Management, 27 (6), 1209-1223.

Stadt Heidelberg. (2003). Satzung zum Schutz des Bereiches "Alt Heidelberg" als Gesamtanlage gemäß $\$ 19$ DSchG (Gesamtanlagenschutzsatzung) vom 26. Juni 2003. Heidelberger Stadtblatt. July 16 2003. Retrieved from http://www.heidelberg.de/ site/Heidelberg_ROOT/get/documents/
heidelberg/Objekt datenbank/30/PDF/30_ pdf_ortsr_6-13_Gesamtanlagenschutzsatzung.pdf

Staatliche Vermögens- und Hochbauverwaltung Baden-Württemberg. (2007). Geschäftsbericht des Landesbetriebs Vermögen und Bau Baden-Württemberg 2006. RetrievedDecember 10, 2013, from http://www.vbv.baden-wuerttemberg.de/pb/site/pbsbw/get/ documents/ mfw/PB5Documents/ pdf/vb/ VB-BW_Geschaeftsbericht_2006.pdf

Staatliche Vermögens- und Hochbauverwaltung Baden-Württemberg. (2008). Geschäftsbericht der Staatlichen Vermögensund Hochbauverwaltung Baden-Württemberg 2007. Retrieved December 10, 2013, from http://www.vbv.baden-wuerttemberg.de/pb/site/pbs-bw/get/documents/ $\mathrm{mfw} / \mathrm{PB} 5$ Documents/pdf/ge/Geschaeftsbericht-2007_VBV.pdf

Staatliche Schlösser und Gärten BadenWürttemberg (2013). Schloss Heidelberg: SpitzenpositionalsBesuchermagnetbehauptet [Press Release]. Retrieved from http://www. schloss-heidelberg.de/presse/pressemeldungen/pressemeldungendetailansicht/?tx_ fufdampresse_pi2 $\% 5 \mathrm{Bdoc} \% 5 \mathrm{D}=513463$

Statistisches Landesamt Baden-Württemberg. (2013). Beherbergung im Reiseverkehr: Stadt Heidelberg.Retrieved December 10, 2013, from http://www.statistik-bw.de/ SRDB/Tabelle.asp?R=GE221000\&H=9\&U $=02 \& \mathrm{~T}=08065012$

United Nations. (2010). International Recommendations for Tourism Statistics 2008. Department of Economic and Social Affairs, Statistics Division. Retrieved from http:// unstats.un.org/unsd/publication/SeriesM/ seriesm_83revle.pdf

Vecco, M. (2010). A Definition of Cultural Heritage. Journal of Cultural Heritage, 11, 321324.

Wimmer, M. (2011, March 1) Heidelberg Liebling der Touristen. Merian Die Lust am Reisen. Retrieved from http://www.merian. de/magazin/heidelberg-liebling-der-touristen.html 